Trinity College

Trinity College Digital Repository

Faculty Scholarship

$3-2015$

Slave or Free? White or Black? The Representation of George Latimer

Scott Gac

Trinity College, scott.gac@trincoll.edu

Follow this and additional works at: https://digitalrepository.trincoll.edu/facpub

Part of the African American Studies Commons, and the United States History Commons 


\title{
Slave or Free? White or Black? The Representation of George Latimer
}

\author{
SCOTT GAC
}

HROUGHOUT the fall of 1842 , the biggest news story
in Boston was the capture of fugitive slave George Latimer (1819?-96), whom the papers called "the man who stole himself." In early October, Latimer, by many accounts a diligent worker, had fled Southern enslavement along with his expectant wife. The two made their way to New England, but soon their owner discovered their whereabouts, and George Latimer was arrested and tried in Boston. His case, which became a benchmark in 1840 os American history, roused New England antislavery advocates, recalibrated local and national understandings of slavery and freedom, and calcified divisions of state-Massachusetts versus Virginia-and nation-North versus South. George Latimer, the traditional narrative goes, helped send the nation down the divided path to civil war. ${ }^{1}$

\footnotetext{
${ }^{1}$ Uncertainty over Latimer's birth date stems from the difference between his narratives (1819) and in U.S. Census records (1821). "Great Annual Jubilee," Liberator, 1 August 1843; "Latimer's Life," Latimer Journal and North Star, 23 November 1842; Latimer Journal, 18 November 1842; "Case of George Latimer," Liberator, 28 October 1842; "The Latimer Case," Liberator, 25 November 1842; "Report on the Latimer Case," Niles' National Register, 28 January 1843, pp. 341-43. Mary Gleason McDougall, Fugitive Slaves (1619-1865) (Boston: Ginn and Company, 1891), pp. 39-40, and Asa J. Davis, "The Two Autobiographical Fragments of George W. Latimer (1820-1896): A Preliminary Assessment," Journal of the Afro-American Historical and Genealogical Society 1 (Summer 1980): 4, 12-13. James Oliver Horton and Lois E. Horton, In Hope of Liberty: Culture, Community and Protest among Northern Free Blacks, 1700-186o (New York: Oxford University Press, 1997), pp. 229-30, and William M. Wiecek, "Latimer: Lawyers, Abolitionists, and the Problem of Unjust Laws," in Antislavery Reconsidered, ed. Lewis Perry and Michael Fellman (Baton Rouge: Louisiana State University Press, 1979), pp. 219-37. This essay developed from research at the
}

The New England Quarterly, vol. LXXXVIII, no. 1 (March 2015). (C) 2015 by The New England Quarterly. All rights reserved. doi:10.1162/TNEQ_a_00436. 
But for all we know of the Latimer who set the nation on fire-his escape and trial—we know little of the Latimer whose light skin and unimpressive intellect unsettled many antislavery leaders. Who was this man? A fugitive from slavery, to be sure, Latimer went on to live in freedom for more than fifty years. To view George Latimer as an individual rather than as an antislavery activist moves his story away from the coming clash of regional titans to a space bounded by representation, cultural politics, and the color of one's skin. Here one finds Latimer a lightly complected freed fugitive whom William Lloyd Garrison and Frederick Douglass thought daft; here is the flash-in-the-pan antislavery celebrity who lived in relative obscurity for most of his life; here is the father of Lewis, a noted industrial-age African American inventor; and here is the icon of antebellum social reform who, despite decades of prideful work as a paperhanger living as a free man in Lynn, Massachusetts, in death was and is celebrated as a famous slave.

Over the course of the nineteenth century, the image of George Latimer was shaped and reshaped by disparate forces. New England in the 184 os was bounded by antislavery protest, debates over miscegenation, and regional clash; in the 189os, by regional reconciliation, antislavery remembrance, and legal segregation. Deemed near-white in his first days of freedom, the renowned runagate was seen by the public as black and near enslaved in his last. In short, the public's shifting attitudes about George Latimer epitomize a trend in racial representation from the age of American slavery to the age of emancipation. ${ }^{2}$

\footnotetext{
American Antiquarian Society in Worcester, Massachusetts, and in seminars on slave narratives with David Blight. I would like to thank the AAS staff and David Blight as well as those who provided valuable insight along the way: Lou Masur, Chris Hager, and Linda Rhoads.

${ }^{2}$ Frederick Douglass, "Letters to Antislavery Workers and Agencies [Part I]," Journal of Negro History 10.4 (October 1925): 65o. The definitive work on the representation of blacks in nineteenth-century America is George Frederickson, The Black Image in the White Mind (Middletown, Conn.: Wesleyan University Press, 1987). See also Mia Bay, The White Image in the Black Mind: African-American Ideas about White People, 1830-1925 (New York: Oxford University Press, 2000).
} 


\section{Encountering George Latimer: The Social Politics} of Antislavery in the 1840 os

George Latimer and his wife escaped bondage in Virginia on 4 October 1842. Three days later, they arrived in Boston and soon crossed the path of William Carpenter, a patron of Latimer's owner. On 19 October, James B. Gray, who held title to Latimer, hired Boston attorney E. G. Austin, who had the fugitive slave jailed as a thief. This initial allegation, fabricated to lure Latimer peaceably into custody, was then exchanged for the more serious charge of deserter from "service and labor." At first, Latimer countered with his own false assertion that a former mistress had freed him. Boston's free blacks, who were then joined by white antislavery activists, demonstrated, forcing a more public airing of the two sides-Latimer's: that Gray was a slanderous, violent owner who made money selling alcohol to blacks; and Gray's: that he had not committed slander by calling Latimer, his property, a thief. Such claims were distractions. The issue at hand was Latimer's liberty. ${ }^{3}$

Inside the courts, where Latimer's case pitted state against state and questions of federal authority loomed, the defense and prosecution stood at odds over whether a slave could escape to freedom within the United States. For some, Article 4, section 2, clause 3 of the Constitution held the answer: "No Person held to Service or Labour in one State, under the Laws thereof, escaping into another, shall, in Consequence of any Law or Regulation therein, be discharged from such Service or Labour." Rather, that individual "shall be delivered up on Claim of the Party to whom such Service or Labor may be due." Others invoked the ${ }_{18} 6$ Massachusetts Supreme Judicial Court decision in Commonwealth v. Aves. Involving a New Orleans slave girl named Med, it was Massachusetts' first notable declaration that a slave was free from the moment she entered the commonwealth's jurisdiction. The precedent had

3See "Latimer's Life"; "Case of George Latimer"; "The Latimer Case"; "Report on the Latimer Case," pp. 341-43; Davis, "Autobiographical Fragments of Latimer," pp. 4, 12-13; and Horton and Horton, In Hope of Liberty, pp. 229-30. 
been set. Those Northern states that had emancipated their slaves continued to shed their legal support for the slave system. By 1841, for example, New York repealed the statute that had given visiting slave owners a nine-month grace period before the slaves accompanying them would receive automatic emancipation. ${ }^{4}$

Latimer activists had even more reason for hope. Judge Lemuel Shaw, then in command of Latimer's case, had written the Massachusetts opinion that had freed Med six years earlier. Shaw based the Med ruling on the antislavery stance of Supreme Court Justice Joseph Story. In 1834, Story had compiled a treatise on contradictory state laws. The tract, a response to the South Carolina Nullification Crisis, marked its author as a Northern John C. Calhoun: as a rule, "no people are found to enforce, or hold valid in their courts of justice any contract, which is injurious to their public rights, or offends their morals, or contravenes their policy, or violates a public law." Because Massachusetts recognized no right to property in slaves, Shaw reasoned that Med should be liberated. ${ }^{5}$

Despite grounds for optimism, Latimer advocates quickly turned on the justice. Shaw denied a hearing on Gray's writ of personal replevin (an action to recover individual property). He was waiting, he explained, for a court ruling on Latimer and the federal Fugitive Slave Act. Such delay fed into the frustration of the protestors. They started to suspect a conspiracy when Judge Story fell ill and Latimer's federal court date was postponed. Story was now "the Slave catcher in chief for the New England States." Long before John Brown brought violence to the antislavery mainstream, Boston activists declared that "the

\footnotetext{
${ }^{4}$ New York Governor William Henry Seward, future Republican stalwart and cabinet official in the Lincoln administration, was instrumental in battling Virginia over the Fugitive Slave Clause, and he instituted a number of measures to protect fugitive slaves. See Walter Stahr, Seward: Lincoln's Indispensable Man (New York: Simon \& Schuster, 2012), pp. 67-75.

${ }^{5}$ Joseph Story, Commentaries on the Conflict of Laws (Boston: Hilliard, Gray, and Company, 1834), p. 95, and Paul Finkelman, The Law of Freedom and Bondage: A Casebook (New York: Oceana Publications, Inc., 1986), pp. 73-76. Judge Shaw, though, earned abolitionists' wrath in 1851 when he decided against freeing fugitive slave Thomas Sims.
} 
slave never shall leave Boston, even if to gain that end our streets shall pour with blood."6

Latimer's case perched precipitously on an American fault line. Along with the debate and resolution of the Three-fifths Compromise and Commonwealth v. Aves, the Latimer case posed the question, Are slaves possessions or people?7

By the mid-1840s, the British example established in Somerset (1772), which refuted the principle of "property in man" on English soil, and the Med case, which found slavery in opposition to natural rights, provided a strong legal foundation for antislavery. As James Oakes has shown, it rested on the notion that "there was no such thing as a constitutional right of property in slaves." John Quincy Adams phrased it in the positive: "the Constitution of the United States recognizes slaves, held within some of the States of the Union, only in their capacity as persons." But such a grandiose conceptualization appeared beyond the ken of participants in the Latimer debate. The case, assigned to District Judge Peleg Sprague due to Story's poor health, reached a settlement before a legal decision was delivered: the four hundred dollars collected by antislavery supporters secured Latimer's freedom. A month later, Massachusetts leader Charles Sumner guessed that Story "would have felt bound to order the poor creature into slavery."

The public argument over Latimer's status coalesced, nonetheless, around his basic humanity—or, more specifically, around certain superficial aspects of it. Both the champions of freedom and of slavery agreed on his intelligence levellow_and skin color_-light. From these mutually acknowledged

\footnotetext{
${ }^{6}$ Unidentified abolitionist "chairman" and "newspaper" quoted in Charles Warren, History of the Harvard Law School and of Early Legal Conditions in America, vol. 2 (1908; repr. New York: Lawbook Exchange, 1999), pp. 24-25.

${ }^{7}$ Eric Foner, The Story of American Freedom (New York: W. W. Norton, 1999), pp. xii-xxii, 47-68, and James Oakes, "The Political Significance of Slave Resistance," History Workshop 22 (Autumn 1986): 104-5.

${ }^{8}$ James Oakes, Freedom National: The Destruction of Slavery in the United States, 1861-1865 (New York: Norton, 2013), pp. 8-26; Adams qtd. p. 19. Warren, History of the Harvard Law School, pp. 24-25, 502; Sumner qtd. p. 25.
} 
characteristics, however, each side framed a different call to action.

Slave owner Thomas Gray was the first to provide a description of the soon-to-be-famous fugitive: "Ran away on Monday night last, my Negro man called George Latimer."9 The advertisement printed in the Norfolk Beacon on 15 October 1842 was, on some levels, typical. "He is about five feet three or four inches high, about twenty-two years of age," Gray noted; "his complexion is bright yellow, is of a compact, well-made frame, and is rather silent and slow-spoken." Readers knew that an enslaved, lightly complected African American ("my Negro man," "yellow skin") had fled ("ran away on Monday night last"). But unlike a fugitive slave notice in which the master opened a negotiation-If you come back, it would say, I will "return you to your former beloved owner"-Gray's did not play to paternalistic paradigms. Irritated slave owners scolded fugitives, portraying them as "saucy," "ungrateful," or "insolent," but Gray's writing lacked such passion. And while countless runaway announcements mapped the brutality of slavery, black bodies identified by parts missing, maimed, or scarred, Gray's limited the bodily sketch of Latimer to height ("five feet three or four inches"), age ("about twenty-two"), and general features ("bright yellow" complexion and "a compact, well-made frame"). ${ }^{10}$

Though Latimer had previously attempted escape, Gray sidestepped another custom and made no mention of his slave's penchant for freedom. The announcement for Latimer's wife, Rebecca, not owned by Gray, acknowledged her husband, described her physically as a "dark mulatto copper colored" who was "at this time obviously [pregnant]," mentally as "selfpossessed," and predicted that "she will in all probability endeavor to reach some one of the free states." Gray refused to

\footnotetext{
9“Great Annual Jubilee," Liberator, 1 August 1843; Norfolk Beacon, 15 October 1842 , qtd. in Davis, "Autobiographical Fragments of Latimer," p. 3, also p. 6.

${ }^{10}$ Norfolk Beacon, qtd. in Davis, “Autobiographical Fragments of Latimer,” p. 3, also p. 6. Slave advertisements qtd. in David Brion Davis, Inhuman Bondage: The Rise and Fall of Slavery in the New World (New York: Oxford University Press, 2006), pp. 133-34. Elizabeth R. Varon, Disunion! The Coming of the Civil War, 1789-1859 (Chapel Hill: University of North Carolina Press, 2008), p. 18.
} 
portray Latimer with as much regard. He was a "silent and slow-spoken" slave apparently too dim to fancy freedom. ${ }^{11}$

Slave owners, of course, often disparaged their slaves' abilities, for a conviction about black intellectual inferiority undergirded American slavery. What is more troubling for the modern historian is to find abolitionists agreeing with Gray about Latimer's dull wit as well as his light skin and status as a slave runaway. Their accord on the last counts is unsurprisingLatimer appeared white and he was a fugitive. To present him as a simpleton, a simpleton at liberty, though, defied the abolitionist mission.

For antislavery advocates, the ill effects of slaveryit numbed minds, warped morals, and broke apart slave families - were vanquished by freedom. But Latimer appeared to challenge this narrative. White Bostonians tried to craft for him their standard fugitive story in which self-determination equaled progress, but with Latimer, a bold, decisive, and heroic flight to Northern salvation proved difficult to believe. Indeed, some struggled to find constructive words to apply to the runaway, who, time and again, was judged better as a physical than a cerebral specimen: Latimer was a "good looking mulatto" with "strong, muscular frame," an escaped slave who was "represented to be more white than black."12 Activists like William Lloyd Garrison and Nathaniel Peabody Rogers found him "less fluent" than other escapees and noted that, while he spoke "intelligently, and told his story well" and "his answers are very correctly given," the famous fugitive clearly had "less strength of mind" than other slave runaways. ${ }^{13}$ His "great accuracy in dates, and care in details" was, it seems, the highest praise that could be bestowed on his intellect. ${ }^{14}$

\footnotetext{
${ }^{11}$ American Beacon (Norfolk), 15 October 1842, qtd. in Davis, "Autobiographical Fragments of Latimer," p. 3, and Fergus M. Bordewich, Bound for Canaan: The Epic Story of the Underground Railroad, America's First Civil Rights Movement (New York: Amistad, 2005), p. 108.

12"Case of George Latimer"; "Latimers Life"; and Charles Francis Adams, HouseNo. 41 (Boston: n.p., 1843), p. 21.

13"Antislavery Melody," Liberator, 20 January 1843, and "Latimers Life."

14"Latimers Life."
} 
Latimer's light skin, an attribute that often signaled superiority for even the most progressive social activist, further complicated the abolitionists' dilemma. For years, white antislavery leaders had used light-skinned slaves as showpieces, their near whiteness an indication of both degradation and superiority: a mark of slavery's injury, an outward sign of intimate sin among master and slave; and a mark of advantage, a light complexion generally taken to suggest a highly developed intelligence and beauty. ${ }^{15}$ Caught in a web of their personal perceptions (where Latimer was unintelligent), activist politics (where fugitive slaves were noble), and cultural politics (where light-colored skin took preeminence), Boston's antislavery advocates seemed schizophrenic. In one moment they declared Latimer humanity's redeemer and in the next derided him as a half-wit.

Other prominent blacks more closely accorded with white antislavery activists' vision for them. During the Latimer campaign, many saw fit to celebrate the likes of "Douglass and Remond (both colored)," who time and again "abundantly vindicated their claim to a very high order of talent and character." Such approbation, of course, only underscored George Latimer's apparent deficiencies. When white abolitionistsusing a practiced rhetoric that depicted the freedman's transformation from slavery to autonomy as from darkness to lightreported on gatherings in which the audience could behold Latimer, "the dumb beast," change into a "human being," one wonders how many questioned whether the metamorphosis were incomplete. ${ }^{16}$

Antislavery leaders' misgivings about Latimer did little to dampen the public's interest in the case. During the closing months of 1842 , socially active and socially oblivious blacks and

${ }^{15}$ Julie Roy Jeffrey, Abolitionists Remember: Antislavery Autobiographies of the Unfinished Work of Emancipation (Chapel Hill: University of North Carolina Press, 2008), pp. 71-72.

16 "New-England Anti-Slavery Convention," Liberator, 16 June 1843, and "From the Salem Observer-Latimer Meeting," Liberator, 9 December 1842. See also William L. Andrews, "The Representation of Slavery and the Rise of Afro-American Literary Realism, 1865-1920," in Slavery and the Literary Imagination, ed. Deborah E. McDowell and Arnold Rampersand (Baltimore: Johns Hopkins University Press, 1989), pp. 64-65. 
whites alike, from Massachusetts to Virginia, were riveted as never before by the prisoner's plight. What made Latimer so remarkable? His status as a fugitive from slavery didn't particularly distinguish him, for Boston, as well as New York, Philadelphia, and other Northern urban centers, had witnessed plenty of slave runaways. ${ }^{17}$ Nor can Latimer's importance be attributed to the uproar within Boston's black community. Although he "excited a very deep interest among the colored denizens of the city," his situation was hardly unusual; Northern black neighborhoods, usually relatively safe harbors for fugitives, had repeatedly raised their voices against racial injustice. ${ }^{18}$ The question remains: what made Latimer's case so special?

Today we expect to read that a fugitive slave case incited a riot, and such an expectation is often borne out by the historical record, at least that of the late 1840 os and 1850 os. Our view in general is clouded by that period, in particular by the North's protest of the Fugitive Slave Act of 1850 . Popular and scholarly interest has focused on a number of fugitive incidents, most notably William Henry (The Jerry Rescue of 1851), Anthony Burns (1854), and Margaret Garner (1856). But a few years earlier, in the 1820 s and 1830 , a volatile reaction was neither common nor pervasive. Blacks, either fugitive slaves or free persons, who were kidnapped out of freedom into a life of Southern slavery excited little notice from white urbanites in the early republic. The practice occurred frequently enough that Frederick Douglass would later call the 183 os streets of New York the premier spot "for slave-hunting sport this side of Africa." 19 Partly a white Southern response to Northern emancipation - the gradual, state-driven process that began in

${ }^{17}$ Leslie M. Alexander, African or American? Black Identity and Political Activism in New York City, 1784-1861 (Urbana: University of Illinois Press, 2008), pp. 8889, and Leonard W. Levy, "The 'Abolition Riot': Boston's First Slave Rescue," England Ouarterly 25.1 (March 1952): 92.

18 "Case of George Latimer."

${ }^{19}$ Life and Times of Frederick Douglass, ed. Henry Louis Gates Jr. (New York: Library of America, 1994), p. 648, qtd. in Alexander, African or American? p. 89, and McDougall, Fugitive Slaves, pp. 27-28, 36 . 
the 1780 os and 1790 s and ended in the 1830 and 1840 - - socalled slave-napping exposed the ubiquitous, nationwide prejudice of white America. As Southern perpetrators stole away with their victims, Northern whites, though dismayed, were not sufficiently horrified to mount a sincere political response. William Lloyd Garrison and his Liberator (founded 1831), heralded by historians as the transformative event for American antislavery reform and race relations, in reality required the dedicated activism of free black communities, as well as several decades, broadly to instill its message of immediate abolition. ${ }^{20}$

Latimer's freedom flight, which was enacted in the wake of British emancipation, years of increased antislavery activism, and the formation of the Liberty Party, in 1840 the earliest national political expression of antislavery, quickly converted white apathy into rage. By seeking legal redress, slave owner Thomas Gray inadvertently drew everyday Bostonians into the fray. The event, noted the Latimer Journal and North Star (a paper, as its name implies, devoted to the Latimer affair), was not about "slavery at a distance, but slavery here." "It has now taken possession of our soil," the paper added, directing a screed at the Southern system of bondage. "It has seized on one of our inhabitants, ay, wHITE in color, and dragged him without warrant to prison." Unlike a slave-napping victim, Latimer did not disappear in the middle of the night. He sat, pale in complexion and, though behind bars, surrounded by white activists. Latimer's presence forced Bostonians to acknowledge his plight. ${ }^{21}$

A near-white man in the Leverett Street Jail, a fugitive from injustice, tugged at the hearts and minds of white Bostonians. The implication was frightening: If a white man can be imprisoned (or enslaved), then so can you. "I see him, in imagination, start and grasp his grates, or clutch his hands in mute despair,

\footnotetext{
${ }^{20}$ Richard S. Newman, The Transformation of American Abolitionism: Fighting Slavery in the Early American Republic (Chapel Hill: University of North Carolina Press, 2002), and Graham Russell Gao Hodges, David Ruggles: A Radical Black Abolitionist and the Underground Railroad in New York City (Chapel Hill: University of North Carolina Press, 2010).

${ }^{21}$ Latimer Journal and North Star, 11 November 1842.
} 
at the least noise. He rolls his eyes fearfully and wildly," said Thomas Parnell Beach, a white reformer. "Let the cry of this dear brother from his damp, cold cell, strike on your ear, and nerve you to act as if your own beloved son." Here sympathy edged toward empathy to stir a vigorous social and political response. The examples of such reaction abound: One popular song on Latimer begged listeners to "think of his agony, feel for his pain," while Frederick Douglass challenged, "Men, husbands and fathers of Massachusetts-put yourselves in the place of George Latimer." 22

White audiences seemed to summon their outrage more readily knowing that Latimer could pass as one of them. "He was whiter, and had straighter and lighter hair than many of those before him, who are classed as white men!" announced one antislavery activist at a December 1842 meeting. "Indeed, had anyone not acquainted with him, been required to select a reputed slave from the entire audience, according to his personal appearance, George Latimer would have been one of the very last to be suspected as the person." The color bond was often emphasized: "The White Slaves of the North" ran a headline in the first Latimer Journal. It was but a twist of fate that separated the light-skinned slave from the white abolitionist. ${ }^{23}$

Of course few white antislavery proponents were the offspring of a white slave-owning father and a black slave mother. The reality behind Latimer's appearance-that his mother Margaret Olmstead bore the son of Mitchell Latimer, her brother's owner, to whom she was apprenticed—was a legacy largely lost to the public among the legal details of the case. Latimer found it important, however, and sought to assert it

\footnotetext{
${ }^{22}$ Beach, qtd. in Latimer Journal, 18 November 1842; "Rescue the Slave," American Antislavery Songs: A Collection and Analysis, ed. Vicki Eaklor (Westport, Conn.: Greenwood Press, 1988), p. 420; Douglass, "Letters to Antislavery Workers and Agencies," p. 652 .

${ }^{23}$ "From the Salem Observer-Latimer Meeting"; "The White Slaves of the North," Latimer Journal and North Star, 11 November 1842; my Singing for Freedom: The Hutchinson Family Singers and the Nineteenth-Century Culture of Antebellum Reform (New Haven: Yale University Press, 2007), pp. 176-77; Cheryl Harris, "Whiteness as Property," Harvard Law Review 106 (June 1993): 1709-91; Mary Niall Mitchell, "Rosebloom and Pure White, Or So It Seemed," American Quarterly 54.3 (September 2002): 369-410.
} 
during his struggle. "My father was Mitchell Latimer-a white man," he declared. "My mother was a slave, named Margaret Olmstead." 24

The fugitive's voice was recorded in a three-paragraph dictation to the editors of the Latimer Journal in 1842 . "We give some meagre details of Latimer's life," the editors announced. "We have no doubt of the substantial correctness of the account. He is willing to swear to the truth of every item of importance in it." Where literacy_-"Written by himself"-served to authenticate slave narratives in works by Frederick Douglass and William Wells Brown, white certification- "We have no doubt . . ."-served that function for the Latimer transcript. Such confirmation was, however, less than perfect. Indeed, Southern opponents declared the very first slave chronicle published by the American Anti-Slavery Society, The Narrative of James Williams (1838), transcribed by abolitionist poet John Greenleaf Whittier, an outright fiction. Records of slavery produced by white social activists have historically, in their time and in ours, been viewed as suspect. ${ }^{25}$

The "X" that stood for Latimer's name in public pleas, including his editors' preface to his brief autobiographical narrative, suggests that in the fall of 1842 Latimer was unable to write. Yet illiteracy, widely acknowledged as an effect of slavery, went unmentioned. Perhaps at the time of his incarceration, his ignorance would have raised concerns about the merits of granting Latimer his freedom. On the whole, reports that linked Latimer's past enslavement to mental deficiencies only appeared after he was freed. Skirting the issue, the abolitionist press noted at that time how "his tale exhibits strikingly the

24"Latimer's Life."

25"Latimer's Life"; David W. Blight, A Slave No More: Two Men Who Escaped to Freedom (New York: Mariner Books, 2007), pp. 11-12; Narrative of the Life of Frederick Douglass, An American Slave (Boston: Anti-Slavery Office, 1845); and Narrative of William W. Brown, A Fugitive Slave (Boston: Anti-Slavery Office, 1847). On the vitality of "written by himself," see James Olney, "The Founding Fathers-Frederick Douglass and Booker T. Washington," in Slavery and the Literary Imagination, pp. 46. John Greenleaf Whittier, in Narrative of James Williams, an American Slave (New York: American Anti-Slavery Society, 1838), pp. xvii-xviii, qtd. in Ann Fabian, The Unvarnished Truth: Personal Narratives in Nineteenth-Century America (Berkeley: University of California Press, 2002), p. 82. 
degradation to which the system of slavery reduces its victims" and "the difficulty" Latimer had in "conveying his meaning in the provincialisms which slavery taught him." The Latimer Journal's preface to his life story, which was likely composed before Latimer's release even though it appeared several days after, avoided questioning the fugitive's intelligence and aptitude. Instead, the editors vouched for Latimer's truthfulness, noted his skin color ("very light mulatto"), facial expression ("a mild and intelligent countenance"), and again verified his answers, which, the editors insisted, "show great accuracy in dates, and care in details." 26

Latimer traced his lineage, earliest owners, and the types of work he had performed through to his seventeenth birthday. The shift in language and style from the editors' preface is immediately evident. "I am 23 years old last 4th of July," said Latimer. "I was born in Norfolk, Va." The declarative first person forges his identity to the page. When he was jailed for his master's debts, Latimer reports: "Got on very well, except for food." The newspaper editors allowed the fugitive's compositional style to shine through. ${ }^{27}$

Reports about Latimer's "simple and artless" public persona corroborate the assumption that he, more so than his editors, set the tone in the 1842 narrative. Depicting his parentage in a straightforward manner-whiteness is a matter of fact, not registered as an emotion-the opening of the account exposes Latimer as an antislavery greenhorn. "My mother was a slave, named Margaret Olmsted," Latimer relayed, "who was owned by my father's brother, Edward A. Latimer, of same trade as his brother, and to him my father was apprentice." The famed fugitive spoke to an audience primarily within antebellum Boston, where songs like "Jefferson's Daughter"- “"The daughter of Jefferson sold for a slave! / The child of a freeman for dollars and francs!"-now and then reverberated in the streets. Indeed, in the 1840s, fugitives' stories were almost formulaic-and with good reason. To showcase slavery as the ruin of black and white

\footnotetext{
26"Anti-Slavery Meetings," Liberator, 12 May 1843; "For the Liberator. The Plymouth Co. A. S. Society," Liberator, 27 January 1843; "Latimer's Life."

27"Latimer's Life."
} 
families, highlighting in particular the rape of black women and the fatherless upbringing of illegitimate children, was to speak to a generation steeped in the themes and tones of religious revival. As a social activist, Latimer had a lot to learn. ${ }^{28}$

In his autobiographical explanation, Latimer focused on questions of ownership and work, issues that, it is safe to assume, were important to him. The opening paragraph reveals that following the death of Edward Latimer, an Edward Mallery married Latimer's widow and "boarded out" young George as a "domestic servant until 16 years of age." Thereafter, Latimer hired himself out as a laborer (as a dray driver, for example), paying "a quarter of a dollar a day" to Mallery, who in return clothed his slave. After one year of this arrangement, Mallery hired out Latimer "to a colored man, Mich Johnson." Johnson was "a very hard master" who beat Latimer "frequently across the head with a stick of wood." 29

Suggested by his hiring out his slave, Mallery's fiscal woes are disclosed in the second paragraph. Following fourteen months under Johnson, Latimer reported that he "was arrested by the Sheriff, for a debt of my master." During two weeks in prison, he ate herring, bread, and beef with molasses, and drank sage tea. Latimer was also a maverick. In jail, he let out an Indian cry, "Ehue!" three times. The guard whipped him for the offense. In and out of jail once more, thanks to Mallery's arrears, Latimer was then sold to John Dunson. Working for his new master and as a hired hand, he was a bank watchman, coal measurer, store clerk, and dray driver. ${ }^{30}$

\footnotetext{
28 "Anti-Slavery Meetings" (Latimer, and/or his editors, spelled his mother's name variously as Olmstead and Olmsted); "Jefferson's Daughter," in Eaklor, American Antislavery Songs, pp. 127-28; Fabian, Unvarnished Truth, pp. 79-116. An example of a mature antislavery fugitive slave narrative was penned by Frederick Douglass in 1855: "Slavery has no use for either fathers or families, and its laws do not recognize their existence in the social arrangements of the plantation. . . . He [the father] may be white, glorying in the purity of his Anglo-Saxon blood; and his child may be ranked with the blackest slaves. Indeed, he may be, and often is, master and father to the same child. He can be the father without being a husband, and may sell his child without incurring reproach" (Douglass, My Bondage, My Freedom [New York: Miller, Orton and Mulligan, 1855], pp. 39-4o).

29"Latimer's Life," and Davis, "Two Autobiographical Fragments of Latimer," pp. $7-8$.

30"Latimer's Life."
} 
Latimer ended his tale on his recent years in slavery, reasoning for liberty, and 1842 escape. The death of John Dunson returned Latimer to the ownership of Edward Mallery, who in 1839 sold the nineteen-year-old to James B. Gray, "a passionate man" who "would strike a white man as soon as a colored." Gray, a store owner who, Latimer claimed, "made all his money selling liquor to colored people," beat his slave with feet and fists, cowhide and sticks. After briefly mentioning a failed 1840 escape, Latimer recounted that he started to save money for another attempt, one that would include his wife. "I have thought frequently of running away even when I was a little boy," he noted. "I have frequently rolled up my sleeve, and asked- Can this flesh belong to any man as horses do?"” This line, a strained, grand gesture about the right to property in man, suggests the influence of his abolitionist editors. His conclusion- "I expected if I was carried back, I would be beaten and whipped 39 lashes, and perhaps be washed in pickle afterwards"-invites suspicion as well. ${ }^{31}$

By the time the autobiographical segment appeared on 23 November 1842, Latimer's freedom had been purchased; the construct of his last line, "I expected . . .," signaled a fear that had since subsided. Still, his piece stood in stark contrast to the majority of the coverage in the white antislavery press. In his own story, Latimer focused on work and physical treatment, what he consumed, and how others handled his body. Latimer's position as a store clerk, along with his quantification of events in his story-" 39 lashes," "16 years of age," "four weeks less two days," and "a quarter of a dollar a day" - suggests an ability for numbers. His numeracy, no doubt, helped him to understand the world in ways that he failed to express in words; indeed, he may have developed a capacity to understand math before he could read and/or write. In any case, white antislavery advocates seemed uninterested in whether, how, or how many times Latimer was being beaten as a slave or what he ate and drank when in jail. They judged George Latimer by what they saw, his skin color and his expressions, and they built their judgments upon it. 
Together, the two tales of 1842 , one fashioned by the fugitive and the other by the white press, furthered Latimer's cause. They anchored the case for his freedom on a number of fronts.

The Latimer autobiography jump-started a conversation about how an institution crafted for toil ostensibly stymied the will to work. George Latimer, both a slave and a slave who hired himself out, wanted to work, a desire that contradicted the notion espoused by many Southern slave owners that discipline and brutality were necessary to ensure chattel diligence. At the same time, Latimer challenged white Bostonians to appreciate escaped slaves for their skill in manual labor. In effect, the famous fugitive shaped the denial of the right to work, or, for slaves, to work with the least impediment, as an obstacle to individual liberty.

The fugitive's status as a hired hand, employment that he secured himself or that his master secured for him, spoke to significant changes that were taking place in American society. Foremost among them was a twinned concept at the center of the young nation's political organization; that is, that the propertyless did not deserve a political voice, and wage labor equaled dependence. By 1830, however, political participation had broadened, with white male suffrage having become nearly universal, and, in turn, notes James McPherson, "one’s labor power became ... a form of property," an expression of freedom. The trajectory of antislavery reform, which increasingly accommodated notions of free labor, attests to Northern wage earners' intensifying belief that workers, even those with black skins, were endowed with some form of independence. In his autobiographical piece, Latimer focused on work (tending grocery stores, dray driving) and independence within slavery (his Indian cry, finding employment, and banking his wages- "I had been saving for some time") to build an argument for his emancipation. ${ }^{32}$

${ }^{32}$ James M. McPherson, Abraham Lincoln and the Second American Revolution (New York: Oxford, 1992), p. 49; Orlando Patterson, "Freedom, Slavery, and the Modern Construction of Rights," Historical Change \& Human Rights: The Oxford Amnesty Lectures, 1994, ed. Olwen Hufton (New York: Basic Books, 1995), pp. 13334; "Latimer's Life"; Davis, "Two Autobiographical Fragments of Latimer," pp. 8-9; 
Latimer situated himself within an interesting space. When the post-Revolutionary generation of white New Englanders discussed liberty, they referenced such fundamentals as freedom of religion, speech, assembly, the press, and the inviolability of property. When slaves were classed as possessions, they were consequently seen to reside in a dependent state. Because they were by definition unfree, liberty and independence were not terms that could be applied to them. But due to his light complexion and his demonstrable work ethic, Latimer, temporarily residing in a state of freedom (even though imprisoned), was viewed by antislavery advocates as meriting the personal liberties the Revolution had bequeathed to those with white skins. Latimer's uncertain condition thus exposed the fluidity of early American racial categories, a system in play for many in the North as well as the South, where black men were slaves and white men were citizens. ${ }^{33}$

The words and deeds of Latimer and of his white antislavery supporters framed the fugitive as an independent, eager-towork man sitting in a Boston jail, denied the privileges of (near) whiteness, particularly the right to a trial by jury and the writ of habeas corpus (which had been largely superseded by Gray's writ of personal replevin). ${ }^{34}$ Latimer's case was thus secured on political, economic, and legal grounds.

Latimer and supporters sought the refuge of the spiritual realm too. "Men of Massachusetts! Come up by the thousands

Eric Foner, Free Soil, Free Men, Free Labor (New York: Oxford University Press, 1995); Sean Wilentz, Chants Democratic: New York City and the Rise of the American Working Class, 1788-185o (New York: Oxford University Press, 1984).

${ }_{33}^{3}$ McPherson, Abraham Lincoln, pp. 46-49; David Roediger, The Wages of Whiteness: Race and the Making of the Modern American Working Class (1991; repr. New York: Verso, 1999), pp. 3-5, 43-52, 65-77; Robert Pierce Forbes, The Missouri Compromise and Its Aftermath: Slavery and the Meaning of America (Chapel Hill: University of North Carolina Press, 2007); Joanne Pope Melish, Disowning Slavery: Gradual Emancipation and "Race" in New England, 1780-186o (Ithaca: Cornell University Press, 1998); Matthew Frye Jacobson, Whiteness of a Different Color: European Immigrants and the Alchemy of Race (Cambridge: Harvard University Press, 1998), pp. 2931: Peter Kolchin, "Whiteness Studies: The New History of Race in America," Lournal of American History 89.1 (June 2002): 154-73.

${ }^{34}$ Warren, History of Harvard Law School, p. 24, and Benjamin Reiss, The Showman and the Slave: Race, Death and Memory in Barnum's America (Boston: Harvard University Press, 2001), pp. 6-7. 
to the city on Monday next," commanded the Latimer Journal. "The victim is ready for the altar. His garlands are chains! His bracelets handcuffs! His crown is a crown of thorns!"35 Imbued with ideals from the Second Great Awakening, white Bostonians not only accepted Latimer's cause as their own, they came to see it as means to their own salvation. Like Christ's, Latimer's martyrdom would lift the burden of sin. ${ }^{36}$ "I remembered that George Latimer represented more than two millions of human beings, who were bleeding and writhing in bondage, and upon whose offspring all this accumulated suffering was entailed," said Nathaniel Rarney in the summer of 1843 as he explained why he was writing a check for the antislavery cause. ${ }^{37}$

The escaped slave played his part well. A message from his jail cell was shared with clergymen, who read it to their parishioners. The fugitive requested "an interest in your prayers, that he may be released from his unjust imprisonment, and preserved from the sufferings he may be called to endure, if reduced to slavery." "Prayers for Deliverance" read the headline in the Liberator, which reprinted the request. ${ }^{38}$ Latimer-a stand-in for Christ and, thus, an object of veneration-consequently remained at a distance from the reform community rather than nearby or part of it.

Frederick Douglass understood the precariousness of the arrangement. "Behold the thing!" Douglass shouted out during his lectures. At first, he used this device to highlight his own being as property in the South. Soon, though, he vented a similar accusation at Northerners, charging his antislavery mentor William Lloyd Garrison of objectification as well. The paternalism of white reformers fit well with their goal to summon sympathy for slaves, but it also furthered interracial tension as

\footnotetext{
${ }^{35}$ Latimer Journal, qtd. in Davis, "Two Autobiographical Fragments of Latimer," p. 5 .

${ }^{36} \mathrm{For}$ a deeper analysis of white salvation and white racial discourse, see Jodi Melamed, Represent and Destroy: Rationalizing Violence in the New Racial Capitalism (Minneapolis: University of Minnesota Press, 2011), p. xi.

${ }^{37}$ Nathaniel Rarney, Letter to the Editor, dated 29 August 1843, Liberator, 15 September 1843 .

${ }^{38}$ Latimer Journal, 11 November 1842 , and "Prayers for Deliverance," Liberator, 4 November 1842 .
} 
black bodies were forced to absorb white emotion: look, here, at the slave-feel his degradation, cry for his lost family, and lament the terror of the lash. ${ }^{39}$

George Latimer suffered more in this regard than did those slaves who were more skilled with written and verbal expression than he. When compared to the antislavery sensation of 1842 , fugitive slave Frederick Douglass, Latimer was almost always seen as the lesser man. The Liberator distinguished between the two: in May 1843- "Latimer is a good looking young man, of rather light complexion, and tells his story in a simple and artless manner. . . . Frederick Douglass is a man of a higher order"; in June- "The celebrated fugitive, George Latimer . . . is but a single shade darker than that of the whitest of us. Messrs. Douglass and Remond (both colored) ... abundantly vindicated their claim to a very high order of talent and character." The invidious parallels persisted. Commenting on the men's deaths, Douglass's in 1895 and Latimer's in 1896, the Nation described the two as "unequal in intellectual capacity." 40

To be sure, the competition was daunting. Northern white activists viewed the shy fugitive and asked, What is the effect of freedom on the slave? They then turned to Douglass, who relished the spotlight and for many embodied Emerson's "representative man," and found Latimer lacking. ${ }^{41}$ Latimer's "uneducated" mind compelled white abolitionists to recognize that some of slavery's evils were not easily overcome. Many activists on both sides of the racial divide, though, were unwilling to acknowledge that freedom for slaves was, perhaps, not all antislavery propaganda made it out to be. Instead, they increasingly framed Latimer as Frederick Douglass's foil.

${ }^{39}$ Douglass, qtd. in “Anti-Slavery Meetings”; Elizabeth B. Clark, “'The Sacred Rights of the Weak': Pain, Sympathy, and the Culture of Individual Rights in Antebellum America," Lournal of American History 82.2 (September 1995): 463-93; Saidiya V. Hartman, Scenes of Subjection: Terror, Slavery, and Self-Making in Nineteenth-Century America (New York: Oxford University Press, 1997).

40 "Anti-Slavery Meetings"; "New-England Anti-Slavery Convention," Liberator, 16 June 1843; "A Band of Singers," Nation, 1 October 1896, p. 255.

${ }^{41}$ Lawrence Buell, "Autobiography in the American Renaissance," in American Autobiography: Retrospect and Prospect, ed. Paul John Eakin (Madison: University of Wisconsin Press, 1991), p. 57. 
Whereas Latimer offered "a very intelligent and expressive countenance," Douglass "was a living, speaking, startling proof of the folly, absurdity and inconsistency (to say nothing worse) of slavery." ${ }^{2}$

\section{Remembering George Latimer: The Science of Racial Separation in the 189 os}

At times, Frederick Douglass was gracious. Attacked by Judson Hutchinson in 1854- "I despise the slave who calls the Constitution anti-slavery"-Douglass brushed him off, calling the noted antislavery musician an "impulsive and warm-hearted man." Douglass could be ornery too. That same year, George Latimer was arrested for picking pockets. "GEORGE LATIMER," Douglass cried, "formerly a slave for whom there was much sympathy manifested a few years since has shown himself unworthy the confidence of those who assisted him." He continued, "The prisoner has for a longtime borne a bad reputation." 43

At the height of the 1842 debacle, Douglass had wondered, "What crime has George Latimer committed?" Twelve years later he knew. Latimer, one imagines Douglass thinking in full scorn, had wasted his freedom. The African American leader, who is often noted for his conviction that freedom is a state of mind, no doubt thought freedom signaled a commitment too. By the mid-185os, Douglass appeared resigned that Latimer would forever be the foolish fugitive whose speech, an 1843 issue of the Liberator noted, "all interlarded [as it is] with those sagacious and curious remarks humanity will make when it is uneducated," shows that he has "less strength of mind" than most former slaves who were fortunate enough to escape their bondage. ${ }^{44}$

\footnotetext{
42"Anti-Slavery Melody"; "Anti-Slavery Meetings"; "Latimer Meeting. From the Salem Observer." On the importance of literacy and perceived intellect among fugitive slaves, see Andrews, Representation of Slavery, pp. 62-65.

43 Judson J. Hutchinson, "A Prompt Disclaimer," Liberator, 26 January 1854; Douglass, "A Prompt Disclaimer," Frederick Douglass's Paper, 23 February 1854; Douglass, "George Latimer," Frederick Douglass's Paper, 24 February 1854.

${ }^{44}$ Douglass, "Letters to Antislavery Workers and Agencies," p. 651; "Anti-Slavery Meetings."
} 
The Douglass comment, which offers a rare glimpse into Latimer's life between 1850 and 1890 , posed liberty more as a burden than a benefit. Over time, Douglass's critical view of his fellow fugitive slave took hold, supported by Latimer's post-emancipation struggle. Seemingly not dynamic or bright enough to make ends meet via the antislavery reform circuit, Latimer worked as a paperhanger and, with the help of his young son, peddled issues of the Liberator. From census records and his children's recollections, one learns that Latimer abandoned his family in 1858 . Perhaps a life of petty crime and manual labor proved too much of an embarrassment. An affair of the heart may also have been responsible-Latimer remarried in 1865 (a son, Charles, was born in 1869). After the death of his second wife, he married once more in 1884 . Whatever the reason for his departure, the effect on his first family was harsh. Rebecca Latimer soon surrendered her three boys to a state institution in Springfield, Massachusetts. ${ }^{45}$

Little is known about Latimer in the years from $185^{8}$ until the 1890 os beyond what is found in the census records. From his escape until his death, he lived in and around Boston: Chelsea in 1850 , Charleston in 186o, Lynn in 1870 , Boston in 1880 , and Lynn, again, in the 189os. A photo of Latimer, which likely dates to the 188 os, shows a balding man in search of distinction (see fig.). Latimer sits proudly, a bit rigid in a dark-colored vest marked with "PF," the letters of a local Freemason society. Clutching the arm of a chair, his hand forms a fist, which presents his pinkie ring for full display, while his eyes, frozen and intent, look into the distance to the viewer's left. Latimer's jacket puffs out and wrinkles over arms and shoulders. Constructed of a heavier fabric, the ceremonial vest neatens out the billows of the jacket to provide a sense of order. This tidiness is reflected in Latimer's face, where well-kept whiskers styled in late nineteenth-century mustachio form demand attention. The day laborer clearly had striven for his best presentation. The

\footnotetext{
${ }^{45}$ James P. Johnson, "Lewis Howard Latimer: The Career of a Black Inventor," Long Island Historical Journal 6.2 (1992): 224-25.
} 


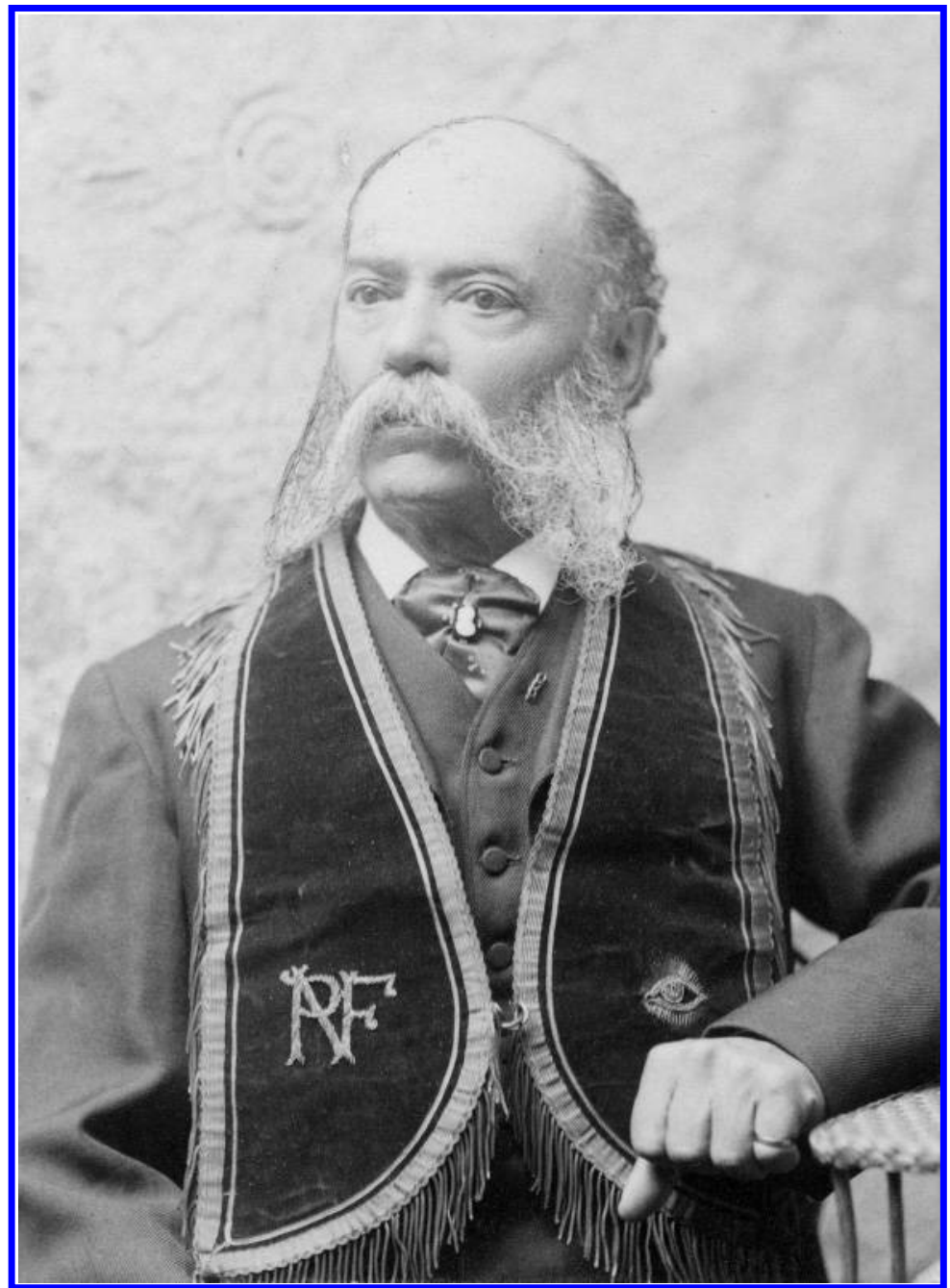

George Latimer in the 1880s. Image Courtesy of the Ohio Historical Society.

nervousness and sincerity that emanate from the photo lend it a certain poignancy. ${ }^{46}$

${ }^{46}$ An Ohio State professor who became an expert on fugitive slaves and the Underground Railroad in the 195 os and 1960 s acquired the photograph of Latimer, after which it found its way into the Ohio Historical Society. 
Latimer returned to the public's eye in 1895 , when friends in Lynn staged a seventy-fifth birthday benefit to help alleviate his poverty, and in 1896 , when he died. ${ }^{47}$ As in 1842 , there was a flurry of newspaper coverage, along with yet another autobiographical sketch from Latimer. Sidestepping his personal struggles, Latimer marked those events that were important to him as a person and as a public figure in antislavery reform.

George Latimer had apparently learned that John Hutchinson, an iconic white antislavery world figure who was the last surviving member of the Hutchinson Family Singers, was writing his memoir. The Latimer incident had been one of several key events that pushed the singing troupe to embrace its social activism in the 1840 s, and their popularization of the antislavery message had propelled them to musical stardom in the American North and in England. In 1843, Latimer and the Hutchinson Family Singers often traveled together on the antislavery lecture circuit.

On 22 November 1894, Latimer visited John Hutchinson at his cottage on High Rock in Lynn. Latimer was then an "oldish man," observed the seventy-three year-old Hutchinson, "with a face whiter than that of the average Caucasian." Latimer, too, Hutchinson recorded, was writing "his reminiscences." The "slow spoken" slave, probably illiterate in 1842 , seemed to have applied himself in freedom. Apparently he had learned to read and write, for the scholar Asa Davis reported seeing Songs for Freedom, a book of lyrics by Latimer, in the family's holdingsa collection that has proved elusive. ${ }^{48}$ By 1894 , however, his health was compromised. Having suffered a stroke, he was partially paralyzed, which robbed him of the ability to work or write and would eventually leave him destitute. Latimer asked Hutchinson to take down his words, for he wanted to thank

47 "Personal and Otherwise," Omaha Daily Bee, 19 July 1895, p. 4; "People Talked About," San Francisco Call, 2 July 1895, p. 5; "Religion and Reform," McCook Tribune [Nebraska], 6 September 1895; "Death of Latimer, A Historic Slave," Springfield Republican, 2 June 1896, p. 7.

${ }^{48}$ John Wallace Hutchinson, "George W. Latimer," in The Story of the Hutchinsons, vol. 2 (Boston: Lee and Shepard, 1896), p. 350; "Prayers for Deliverance"; Davis, "Two Autobiographical Fragments of Latimer," p. 10. 
those who, like the Hutchinson family, had supported him in his effort to escape slavery.

During their meeting, Hutchinson thought Latimer looked, "with a handsome pair of gray side whiskers," like a "prosperous retired banker." Despite Latimer's desperate straits, Hutchinson viewed his old colleague as successful and content, just as he viewed the Civil War as an unquestioned victory for the antislavery movement. Hutchinson, stuck in an older way of seeing the world, was convinced that religious truth would redeem humanity in the battle between "darkness" and "light." For the majority of antislavery activists, however, the war's carnage, along with the plight of former slaves indicated that, the demise of slavery notwithstanding, the millennium was far from imminent. Yet Hutchinson held fast to a belief he frequently broadcast in song, "there is a good time coming." 49

Latimer shared his faith, writing in Songs that when "from the slave the chain be broken ... Christ shall reign, the Prince of Peace." The two men-one black, one white-were blind to the social disarray left in the Civil War's wake. Whereas once the Hutchinson Family Singers, like many white and black antebellum activists, drew on the heightened emotional response of religious revivalism to demand immediate answers to social ills, the immediatism of the Civil War-which brought on a sudden abolition of slavery but cost more than seven hundred thousand lives-raised questions about the usefulness of such idealistic approaches. In the postwar age, many were wary of emotive religious paradigms, a phenomenon that was increasingly being seen as a factor in having prompted the war. As American pragmatism, which rebuffed the notion that faith was the desired endpoint of intellection, gained popularity, Latimer and Hutchinson remained transfixed by religious hope. $5^{\circ}$

${ }^{49}$ Hutchinson, "George W. Latimer," p. 350.

${ }^{5}$ Hutchinson Family, "There's A Good Time Coming" (Boston: Oliver Ditson, 1846). Latimer, Songs for Freedom, qtd. in Davis, "Two Autobiographical Fragments of Latimer," p. 10; my Singing for Freedom, pp. 238-39; Louis Menand, The Metaphysical Club: A Story of Ideas in America (New York: Farrar, Straus, and Giroux, 2001), pp. ixxii. 
But as he turns to the task of narrating his autobiography, gratitude is the emotion that energizes Latimer. "I have known John W. Hutchinson since 1842," he explains. "That was the year I came North." In two paragraphs, Latimer sketches his life, revealing new details about his escape and events thereafter. He and Rebecca had stowed away in "the fore-peak of the vessel" heading north from Norfolk; they then took "a first-class passage" from Baltimore to Philadelphia. The visibly darker-skinned Rebecca traveled "as a servant" until Pennsylvania, "presumably free country," where the Latimers journeyed together "as man and wife." Eleven days after the couple took flight, Latimer was arrested, and he credits William Lloyd Garrison for bringing his situation to the public's attention.

Latimer mentions Chief Justice Shaw, who ruled that Latimer was still a slave, and he thanks the "Rev. Dr. Caldwell, of the Tremont Temple Baptist Society," who raised the money to purchase his freedom from James Gray. In freedom, Latimer told John Hutchinson, he started to attend antislavery rallies, where he first met the Hutchinson Family Singers. Then Latimer highlights how far he has come, first by working as a paperhanger and, second, by distancing himself from his enslavement: "My days in Virginia seem like a dream to me." Latimer closes with a statement reminiscent of the deference and paternalism that tinged many biracial friendships of the Civil War era. "I am glad to add these few words in recognition of the services to liberty of the Hutchinson Family," Latimer says. "And to speak again my sense of gratitude to those who with them aroused the North in an agitation that made freedom possible for me and mine." 51

Whereas Latimer's first autobiographical sketch of 1842 sought to denigrate slavery and his slave master (and ultimately encourage readers to see slavery's transgressions against his person and family on economic, religious, and legal grounds), the second focuses more on the circumstances of his escape and the episode's importance to the antislavery movement (and,

${ }^{51}$ Hutchinson, “George W. Latimer," p. $35^{\circ}$. 
therefore, his centrality to the grand pageant of the Civil War). The 1894 piece depicts a Latimer active in escape ("I started in September ..."; "I secreted myself under the fore-peak . . .), yet passive in emancipation (Rev. Caldwell "raised the money with which I was redeemed ..."; My wife was to be returned to slavery "if I was taken").

Some of that disjunction may be due to the transcription process. Latimer's 1842 autobiographical essay has the marks of being a near word-for-word record of Latimer's oral account. Except for notice of his first marriage ("I was twenty-one when married"), the delivery of his first child ("A short time after my first child was born ..."), and his continued pride in his work ("For forty-five years I pursued the trade of a paperhanger in Lynn"), Latimer's distinctive voice is rarely evident in his second autobiographical offering. In 1894, the interpretive style of John Hutchinson, a man then obsessed with how he himself would be remembered, shines through. Hutchinson's characteristic rhetoric, which touted the contributions of white abolitionists, often to the exclusion of African American actions and influences, dominates his two-volume memoir. For example, recalling a time in 1843: "In my sleigh was Latimer, the recently manumitted slave, whom we had taken in charge under the auspices of the anti-slavery committee [emphasis added]." ${ }^{2}$

Even if we keep the Hutchinsonian influence in mind, it is difficult not to notice that Latimer's 1842 freedom tale is more active and more impassioned than his later account. Admittedly his earlier writing preceded his legal emancipation, the moment from which he measured his gratefulness in later years. But even in the white press, Latimer's persona of the 1890 is less self-determined than his persona of fifty years earlier, when he was a savior ("His crown is a crown of thorns!"), a symbol of Liberty and Right ("he is the representative of every other human being on the face of the globe"), and a fugitive

$5^{2}$ Hutchinson, "George W. Latimer," pp. 350-51; John W. Hutchinson, The Story of the Hutchinsons, vol. 1 (Boston: Lee and Shepard, 1896), p. 78. 
slave ("a self-emancipated brother" and the "man who stole himself"). .53

In 1896, obituaries of Latimer persisted in framing him as dependent, rendering the famed fugitive more as a victim of history than as a maker of it. Certainly he was overshadowed by the white men who helped him. "Some explanation of who he was, and what he did, or rather what was done to him, is necessary," read one memorial; instead of running away, "he and his wife managed to secret themselves in the forepeak of a steamer"; he wasn't a fugitive from slavery, but rather "George Latimer, 75, the first slave hunted on Massachusetts soil"; his arrest, said the New York Times, "loosened the tongue of Wendell Phillips, aroused William Lloyd Garrison, and moved the poet Whittier." To top off the insult, one incensed reader wrote the Times to correct the record: Phillips, he insisted, had been active in reform long before Latimer arrived in Boston. ${ }^{54}$

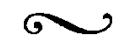

Booker T. Washington, who in the 1890 , along with W .E. B. Du Bois and Ida B. Wells, lifted the heavy mantle of black leadership from the weary shoulders of Frederick Douglass, sought to redefine slavery as an enabling experience. The everpractical Washington proclaimed strength in bondage, going as far as to dub the institution "the school of American slavery." As slaves, Washington argued, the freedmen and freedwomen had learned plenty, enough to be better off than "black people in any other portion of the globe." 55

${ }^{53}$ Latimer Journal, qtd. in Davis, "Two Autobiographical Fragments of Latimer," p. 5; "Resolutions from Latimer Meeting at Faneuil Hall," Latimer Journal, 18 November 1842; "Latimer Meeting in Northampton," Liberator, 9 December 1842; "Great Annual Jubilee."

54"Once on Every Lip," Boston Journal, 4 June 1896, p. 6; "Great Annual Jubilee," Liberator, 11 August 1843; "Geo. W. Latimer," Boston Morning Journal, 2 June 1896, p. 3; "Death of Latimer, A Historic Slave," p. 7; "Obituary," Irish World, 6 June 1896, p. 5; "Wendell Phillips's Beginning," New York Times, 7 June 1896.

55 Booker T. Washington, Up from Slavery (New York: Doubleday, Page \& Company, 1901), p. 16; Washington, qtd. in Andrews, Representation of Slavery, p. 62; Blight, Slave No More, pp. 13-14. 
George Latimer, whether in 1842 or 1894 , was never as keen on slavery as was Washington. Their differences, of course, reflect a generational divide. The 1865 ratification of the Thirteenth Amendment marked Latimer's forty-sixth birthday and his twenty-third year of freedom; Washington was just nine. But the two did share common ground. They agreed on the importance of work, the essential link between labor and liberty. Though Latimer never found slavery empowering, for him toil, whether in freedom or bondage, was.

Latimer, with Washington, therefore accepted the challenge posed to black Americans following the deadlocked national election of 1877 , when, out of a sink-or-swim mentality, the North and South reunited more than a decade after Appomattox. As the federal government withdrew from its military and bureaucratic occupation of the former Confederacy, freed African Americans were told, in effect, that they could no longer turn to the state for assistance. Indifferent to reshaping a flawed social structure, the nation's political leaders largely took leave of their responsibility to address the issue of race as it had been determined by two and a half centuries of American slavery. The proponents of Social Darwinism had triumphed. Individuals, their ability and morality, were to create America's successes and its failures..$^{6}$

The brutal repression of black political rights in the late nineteenth century attested to the new system. Individualism, no matter how eloquently Booker T. Washington stated it, was largely reserved for those with white skin. The mainstream newspapers mapped the transition when George Latimer died. Latimer, a self-motivated individual who had escaped his master, battled the law for liberty, overcome illiteracy, and worked as a free man for more than fifty years, was returned to the status from which he had fled. In death he was a slave, "a historic slave," "a fugitive slave," "the first slave hunted," "hunted

\footnotetext{
$5^{6}$ Heather Cox Richardson, West from Appomattox: The Reconstruction of America after the Civil War (New Haven: Yale University Press, 2007).
} 
as a slave," and "an escaped slave." 57 The words "slavery" and "slave" seemed no longer to refer to bonded labor, which in the 189 os was of course illegal, but to a separate caste of citizens, African Americans.

In the Revolutionary era, the imagery of slavery and freedom was readily found in the writings and speeches of eminent Americans. George Washington, for instance, warned that "the Nation, which indulges toward another an habitual hatred, or a habitual fondness, is in some degree a slave." $5^{8}$ By 1894, slavery having collapsed as an institution, the metaphor had a more troubling resonance. Presidents from Grover Cleveland to Theodore Roosevelt shied away from it, turning instead to the language of "civilization" and "savagery." 59 "Slave" now indicated a black American and "slavery" the system from which all blacks had come. Faced with this cultural turn, it's no wonder that an African American leader like Booker T. Washington sought to frame pre-emancipation enslavement as a galvanizing opportunity for blacks. ${ }^{60}$

In 1842, Latimer's dire circumstances and light complexion led activists to view him as a white savior; in 1896, his status as a black man fixed him, along with the millions of other black Americans, whether born under slavery or freedom, as a member of a once-bonded race. Whereas in the 1840s Latimer confused those who delineated race by sight, in the 189 os his skin color went largely unremarked because race

57"Death of Latimer, A Historic Slave"; "George W. Latimer," Sioux City Journal, 6 June 1896, p. 4; “Geo. W. Latimer," p. 6; "Death of George Latimer," Daily Inter Ocean, 3 June 1896, p. 7; “An Escaped Slave,” Boston Daily Advertiser, 2 June 1896, p. 5 .

$5^{8}$ George Washington, "Farewell Address," The Writings of George Washington, vol. 13, 1794-98, ed. Worthington Chauncey Ford (New York: G. P. Putnam and Sons, 1892), p. 312 .

${ }^{59}$ Frederick Douglass's comments at the Chicago Columbian Fair of 1893 note the shift: "The Dahomians are here to exhibit the Negro as a repulsive savage." Douglass, qtd. in Alan Trachtenberg, The Incorporation of America: Culture and Society in the Gilded Age (1982; repr. New York: Hill and Wang, 2007), p. 221.

${ }^{60}$ For a corresponding statement on the black image and the demise of slavery, see John Stauffer, "Creating an Image in Black," in Prophets of Protest: Reconsidering the History of American Abolitionism, ed. Timothy Patrick McCarthy and John Stauffer (New York: New Press, 2006), p. 267. 
was now defined by science. The biological signature of racial origin was no longer skin but blood and bloodlines. This new system was encoded into state legislation and undergirded the newly legalized system of racial segregation. ${ }^{61}$

Latimer had worked in freedom as a paperhanger for more than four decades, yet in the 1890 , according to the white public, he was a slave. Within the association of black and blackness to a previous condition of servitude, Latimer's paleness lost meaning. In a time when explorations of the color line dominated the courts and culture-to name a few, Mark Twain's Pudd'nhead Wilson (1894), Plessy v. Ferguson (1896), and W. E. B. Du Bois's The Souls of Black Folk (1903)Latimer's complexion faded to black.

What does it mean that in the 1890 os Latimer was a black slave, while in $\mathbf{1 8 4 2}$ he was nearly white and deserving of freedom? The contested terrain that is George Latimer, man and symbol, reveals a pre-war and post-war nation struggling to come to terms with shifting social, political, and cultural realities. In the 189os, Latimer's representation demonstrates that to have been a slave meant that you were black-and to be black meant that you were a slave.

In Latimer's case, it is a slavery that may last forever. The man and his work remain buried beneath a slave past, one that Latimer himself appears to have moved beyond. Such is the paradox of Boston's famous fugitive. Though few believed in his capabilities, Latimer made statements for American individualism in word, work, and deed throughout his life. After fifty-four years of freedom, however, in 1896 the newspapers could remember only the "time when his name was on every lip, in every mind." Latimer was chattel again. The black man who secured a legacy fleeing the white man who called him property found it much harder to escape the ubiquitous and omnipresent bogeyman of slavery that stalked African Americans in the wake of the Civil War. ${ }^{62}$

\footnotetext{
${ }^{61}$ Garrett W. Nichols, “'Clo'es could do de like o' dat': Race, Place, and Power in Mark Twain's The Tragedy of Pudd'nhead Wilson," Southern Literary Journal 46.1 (2013): 110-26.

62“Once on Every Lip," p. 6.
} 
Scott Gac is Program Director of American Studies and Associate Professor at Trinity College in Hartford, Connecticut. He has written on protest music, violence, and the American Civil War. His current book project is BORN IN BLOOD: VIOLENCE AND THE MAKING OF AMERICA. 